\section{Clinical applications of chromosome analysis, from fine needle aspiration biopsies, of posterior uveal melanomas}

\begin{abstract}
Purpose An accurate assessment of prognosis is essential to the clinical assessment of malignancy. In posterior uveal melanoma specific chromosome alterations have been shown to correlate significantly with prognosis; but the procedure is restricted to patients treated surgically, and in consequence has been limited mainly to large tumours. Fine needle aspiration biopsy (FNAB) may provide sufficient material to perform this technique, and allow its use in the in situ assessment of tumours, including small lesions. To deternine the feasibility of this approach we have conducted a pilot study using enucleated tumours.
\end{abstract}

Methods Ten cases of posterior uveal melanoma were studied. In each instance both a test FNAB and a standard tissue preparation were conducted, and the results compared.

FNABs were obtained from enucleated tumours by aspirating cells using a $5 \mathrm{ml}$ syringe with a .25 gauge needle; cells were injected into phosphate-buffered saline, spun down and established in vitro. Conventional short-ternn cultures were established from tumour tissue samples, which were minced prior to the establishment of cultures.

Cytogenetic analysis was performed following standard protocols.

Results Of the $\mathbf{1 0}$ cases examined, full chromosome analysis was obtainable from all standard tissue short-term cultures.

Cytogenetics was successful from cultures of 6 FNAB, with 2 further FNAB producing partial analyses. No major clonal differences were determined between the two procedures.

Conclusions Cytogenetic analysis of FNAB appears to be entirely feasible for posterior uveal melanomas, and may permit an accurate in situ assessment of tumours, including small lesions.
Ke'y arords Uveal melanoma, Cytogenetics,

Prognosis $i n$ situ

The cytogenetic analysis of leukaemias has relevance for both the diagnosis and the prognosis of this malignancy, 'but for most solid tumours chromosome analysis is highly problematic and cytogenetic information is limited with little, or no, clinical benefit. ${ }^{2+}$ Posterior uveal melanomas are unusual in this respect, as they appear to be relatively amenable to cytogenetic analysis, approximately 100 cases having been reported to date. "II Furthermore consistent patterns of chromosomal involvement have been observed, with chromosomes 1, 3, 6, 8 and $Y$ most frequently implicated. " Increasing evidence suggests that certain chromosome abnormalities are more common to tumours of a specific location; in particular tumours with a ciliary body component almost invariably possess alterations of chromosomes 3 and 8 in association." 12 Likewise, choroid melanomas appear to have higher levels of involvement for chromosome 6 and $11,0,7.12$ whilst iris melanomas seemingly exhibit a different repertoire of alterations. ${ }^{1 ;}$

Recently, the significance of chromosome changes in posterior uveal melanoma has been clearly demonstrated, with certain chromosome abnormalities, loss of chromosome 3 and additional $8 q$, having been shown to be a significant predictor not only of survival, but also of disease-free interval. ${ }^{1+15}$ Furthermore, as a prognostic indicator, initial evidence suggests that cytogenetic analysis may be more reliable than other classical prognostic indicators..$^{1+1^{15}}$ In uveal melanoma, the clinical value of cytogenetic analysis seem apparent; however, the procedure repuires fresh tumour material, and as a necessity is therefore restricted to surgically treated tumours. In practice analysis is biased towards large tumours that cannot
K. Sisley :-:

Institute for Cancer Studies

Medical School

Beech Hill Road

Sheffield Unıversity

Sheffield SIO 2RX, UK

Tel: $+44(0) 1142712237$

Fax: +44(0)1142713515

K. Sisley

C. Nichols

R. Farr

I.G Rennie

Department of

Ophthalmology and

Orthoptics

Sheffield Unıversity

Sheffield

UK

M.A. Parsons

Ophthalmıc Sciences Unıt

Sheffield University

Sheffield

UK

R C Rees

Department of Life Sciences The Nottıngham Trent Unıversity Nottıngham

UK

First presented at the annual meeting of the Association for Research in Vision and Ophthalmology, Fort Lauderdale, Florıda, 1997

This work has been supported by the Yorkshire Cancer Research Campaign, grant S 253 
Table 1. Clinicopathological details of the patient:

\begin{tabular}{|c|c|c|c|c|c|}
\hline Case no. & Age (years) & Sex & Tumour location & Coll type & $\begin{array}{l}\text { Mean tumour diameter } \\
(\mathrm{mm})\end{array}$ \\
\hline 1 & 80 & $M$ & $\mathrm{CB} / \mathrm{C}$ & Mixed & 19.65 \\
\hline 2 & 69 & $\mathrm{~F}$ & C & Mixed & 19.1 \\
\hline 3 & 7() & $\mathrm{F}$ & C & Spindle & 15.45 \\
\hline 4 & 67 & $\mathrm{~F}$ & $\mathrm{CB}$ & Mixed & 16.2 \\
\hline 5 & 78 & $\mathrm{~F}$ & CB & Mixed & 15.15 \\
\hline 6 & 76 & $\mathrm{~F}$ & $\mathrm{C} / \mathrm{CB}$ & Spindle & 12 \\
\hline 7 & 56 & $\mathrm{M}$ & $\mathrm{CB}$ & Mixed & 16.7 \\
\hline 8 & 58 & $M$ & CB & Mixed & 15.2 \\
\hline 9 & 82 & $F$ & $\mathrm{CB} / \mathrm{C}$ & Mixed & 18.25 \\
\hline 10 & 58 & $\mathrm{M}$ & $\mathrm{C} / \mathrm{CB}$ & Mixed & 18.05 \\
\hline
\end{tabular}

reasonably be treated by more conservative means. Chronologically, changes of chromosome 3 appear to occur earlier than other chromosome alterations, ${ }^{15}$ i but it is unknown what abnormalities small tumours exhibit, or whether cytogenetic analysis would be of benefit in the assessment of these potentially early lesions. To explore the possible application of cytogenetics to the assessment of small lesions, we have conducted a feasibility study, using test fine needle aspiration biopsy (FNAB), on surgically removed tumours.

\section{Materials and methods}

Ethics approval and informed patient consent were obtained for the removal of tissue prior to commencing the study. A total of 10 tumours was examined, and the clinicopathological data of the patients are presented in Table 1.

For each tumour both a conventional procedure and a test FNAB were conducted. FNAB were performed on the enucleated tumours, by aspirating cells using a $5 \mathrm{ml}$ syringe with a .25 gauge needle, directly from the tumour mass once the globe had been opened. Tumour cells were injected into phosphate-buffered saline (PBS), spun down, and established as cultures. Tumour tissue for conventional short-term cultures was transported to the laboratory in PBS. Upon receipt the specimen was processed by fine mincing with scalpel blades, washing in PBS and resuspending in medium. Medium for both techniques was RPMI supplemented with $20 \%$ fetal calf serum, glucose $(2 \mathrm{mg} / \mathrm{ml})$, fungizone $(3 \mathrm{mg} / \mathrm{ml})$,

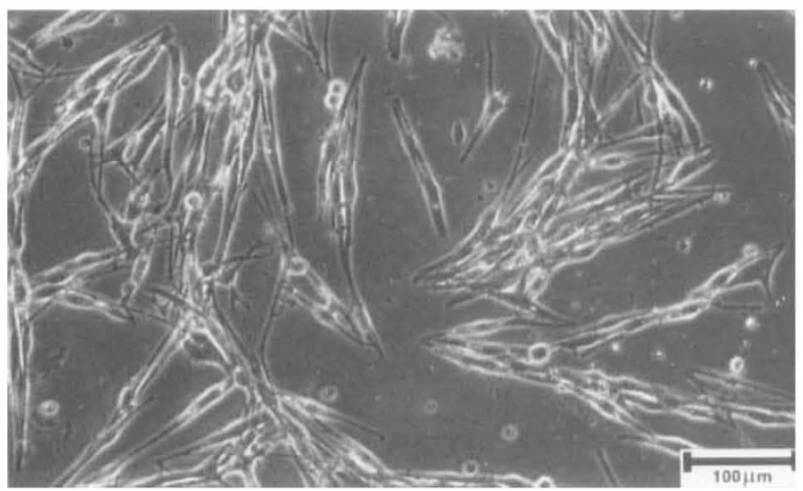

(a)

Fig. 1. Comparison of grouth in culture, from the same wienl melanomm, at i dang: from a standard tissule culture (a) and a FNAB culture (b). Substantially more grouth was found with comerntional procedures compured arith FNAB cultures. penicillin $(100 \mathrm{U} / \mathrm{ml})$, streptomycin $(100 \mathrm{mg} / \mathrm{ml})$ and epidermal growth factor $(10 \mathrm{ng} / \mathrm{ml})$. For both procedures tumour cells were seeded into flat-bottomed tissue culture test-tubes and grown in culture, at $37^{\circ} \mathrm{C}$ with $5 \%$ $\mathrm{CO}_{2}$.

Cytogenetic analysis was performed using standard techniques," with an Olympus microscope and the Powergene system (Perceptive Scientific International) and abnormalities reported in accordance with the ISCN. ${ }^{1:}$

\section{Results}

Both conventional short-term cultures and those established from FNAB were harvested at the same time, at 7 days after initiation of cultures. Growth, in all instances, was more substantial in the conventional short-term cultures (Fig. 1) and, as expected, when the conventional cultures were harvested they produced more material than the FNAB cultures. For comparative purposes the same number of slides was prepared from all samples. The results of cytogenetic analysis, for both procedures, are recorded in Table 2; only the clonal changes are reported. Representative karyotypes from both the short-term and FNAB analysis of one tumour (case 10) are shown in Fig. 2.

The series was composed of a representative admixture of tumour locations and cell types, and no bias for producing successful cytogenetic analysis was found. Of the 10 tumours analysed, results were obtainable from all the conventional short-term cultures and analysis was

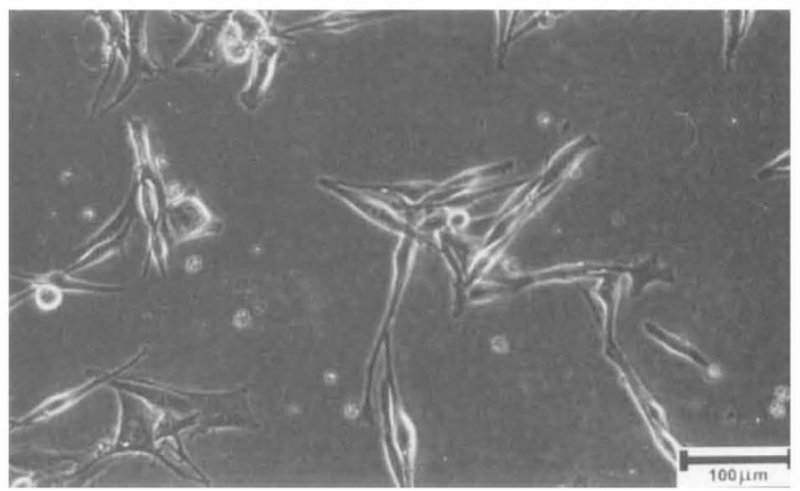

(b) 


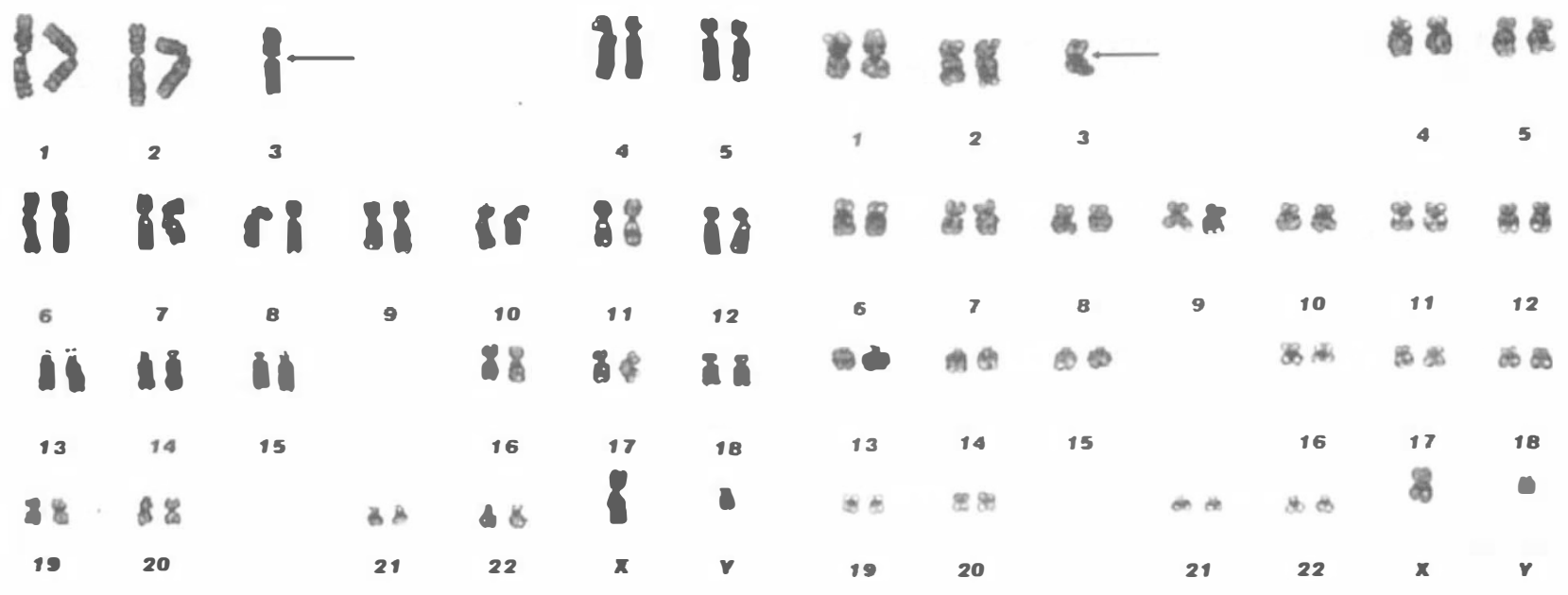

(a)

(b)

Fig. 2. Representative karyotypes from the standard tissue preparation (a) and the FNAB culture (b) of case 10. The same clonal alterations were found in both preparations, and are indicated by arrows.

successful from 6 of the test FNAB. A further 2 FNAB samples produced incomplete analysis (cases 5 and 8), which, with the examination of the remaining cell harvest, would have produced full analyses, as confirmed subsequently (data not shown). The results of 2 FNAB were considered complete failures (cases 6 and 9).
Where analysis was possible on both procedures, comparison of the results demonstrated that all major clonal chromosome changes were present in both the conventional culture and its corresponding FNAB sample. In most instances, the less frequent clonal alterations were also identified by both procedures, although on occasions (cases 2, 5 and 7) the lower

Table 2. Comparison of cytogenetic analysis from conventional short-term cultures, and fine needle aspiration biopsy cultures

\begin{tabular}{|c|c|c|}
\hline Case no. & Conventional short-term cultures & Fine needle aspiration biopsy cultures \\
\hline 1 & $\begin{array}{c}11 \text { cells } 44-46, X,-Y[11], \operatorname{der}(1) t(1 ; 8)(\mathrm{q} 10 ; \mathrm{q} 10)[11],-3[11],+10 \\
{[3], \operatorname{del}(11)(\mathrm{q} ?)[3],+21[6],+22[2][\mathrm{cp} 11]}\end{array}$ & $\begin{aligned} & 10 \text { cells } 44, X,-Y, \operatorname{der}(1) t(1 ; 8)(\mathrm{q} 10 ; \mathrm{q} 10),-3 \\
& 2 \text { cells } 45, X,-Y, \operatorname{der}(1) \mathrm{t}(1 ; 8)(\mathrm{q} 10 ; \mathrm{q} 10),-3,+21 \\
& 3 \text { cells } 44, X,-Y, \operatorname{der}(1) \mathrm{t}(1 ; 8)(\mathrm{q} 10 ; \mathrm{q} 10),-3, \operatorname{del}(11)(\mathrm{q} ?)\end{aligned}$ \\
\hline 2 & $\begin{aligned} & 3 \text { cells } 48, X,-X, \operatorname{del}(1)(\mathrm{p} 36),+\operatorname{del}(1)(\mathrm{p} 36),-3, \mathrm{i}(8) \\
&(\mathrm{q} 10),+\mathrm{i}(8)(\mathrm{q} 10) \times 2,+\operatorname{der}(8) \mathrm{t}(8 ; 8)(\mathrm{p} 23 ; \mathrm{q} 23)\end{aligned}$ & $\begin{aligned} 3 \text { cells } & 48, X,-X, \operatorname{del}(1)(\mathrm{p} 36),+\operatorname{del}(1)(\mathrm{p} 36),-3, \mathrm{i}(8)(\mathrm{q} 10),+\mathrm{i}(8) \\
& (\mathrm{q} 10) \times 2,+\operatorname{der}(8) \mathrm{t}(8 ; 8)(\mathrm{p} 23 ; \mathrm{q} 23) \\
4 \text { cells } & 48, X,-X, \operatorname{del}(1)(\mathrm{p} 36),+\operatorname{del}(1)(\mathrm{p} 36),-3, \mathrm{i}(8)(\mathrm{q} 10),+\mathrm{i}(8) \\
& (\mathrm{q} 10) \times 2,+\operatorname{der}(8) \mathrm{t}(8 ; 8)(\mathrm{p} 23 ; \mathrm{q} 23), \mathrm{i}(17)(\mathrm{q} 10)\end{aligned}$ \\
\hline 3 & $\begin{aligned} 13 \text { cells } & 46, X X, \operatorname{der}(6) t(6 ; 8)(q 16 ; q 13), \operatorname{der}(11) t(6 ; 11) \\
& (p 21 ; q 23), \operatorname{add}(11)(p 15), \operatorname{der}(20) t(6 ; 20)(p 11 ; p 11)\end{aligned}$ & $\begin{aligned} 7 \text { cells } & 46, X X, \operatorname{der}(6) t(6 ; 8)(q 16 ; q 13), \operatorname{der}(11) t(6 ; 11) \\
& (p 21 ; q 23), \operatorname{add}(11)(p 15), \operatorname{der}(20) t(6,20)(p 11 ; p 11)\end{aligned}$ \\
\hline 4 & 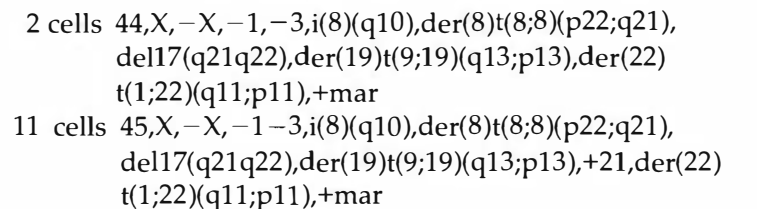 & 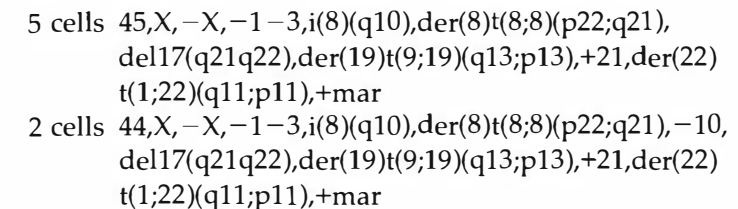 \\
\hline
\end{tabular}

2 cells $44, X,-X,-1-3, i(8)(q 10), \operatorname{der}(8) t(8 ; 8)(\mathrm{p} 22 ; \mathrm{q} 21)$, $-10, \operatorname{del17}(\mathrm{q} 21 \mathrm{q} 22), \operatorname{der}(19) \mathrm{t}(9 ; 19)(\mathrm{q} 13 ; \mathrm{p} 13),+21$, $\operatorname{der}(22) \mathrm{t}(1 ; 22)(\mathrm{q} 11 ; \mathrm{p} 11),+$ mar

53 cells $46, X X,-3+i(8)(q 10)$

610 cells $44-47, X X, \operatorname{del}(2)(q ?)[10],-5[3],-6[3],+\operatorname{add}(6)(q 12)$ [6], $-7[4], \operatorname{add}(8)(\mathrm{q} 24)[4],-10[4],+11[3], \operatorname{add}(12)(\mathrm{p} 13)$ $[10],-14[6],+19[3],-21[3],+22[2],+3 \operatorname{mar}[6][c p 10]$

5 cells $35-44, X X,-3[5],-4[3], \operatorname{add}(6)(q 11)[2], i(8)(q 10)[5]$, Failed $+\mathrm{i}(8)(\mathrm{q} 10)[5],+2 \mathrm{mar},[\mathrm{cp} 5]$, inc

78 cells $39-43, X-Y[8],-1[4],-2[3],-3[3], \mathrm{i}(8)(\mathrm{q} 10)[8]$, $+\mathrm{i}(8)(\mathrm{q} 10)[8],-15[3],-17[3],-20[3],+22[2]$

812 cells $45-47, X-Y[3],-7[3],+22[8],+2 \operatorname{mar}[4][c p 12]$

97 cells $46, X X$

5 cells $45, X Y,-3$

5 cells $45, X Y,-3, i(8)(q 10), \operatorname{del}(18)(p 11)$

2 cells $45, X Y,-3, i(8)(q 10), \operatorname{del}(18)(p 11), \operatorname{del}(20)(p 11 p 11)$

5 cells $41-45, X-Y[5],-3[5], i(8)(q 10)[5],+i(8)(q 10)[5],-20[3]$ $+22[2][c p 5]$

3 cells Analysis incomplete; failed

Failed

3 cells $45, X Y,-3$

6 cells $45, X Y,-3, i(8)(q 10), \operatorname{del}(18)(\mathrm{p} 11)$

3 cells $45, X Y,-3, i(8)(q 10), \operatorname{del}(18)(p 11), \operatorname{del}(20)(\mathrm{p} 11 \mathrm{p} 11)$ 
number of cells available prevented these alterations being considered clonal. Additional anlaysis of the remaining cells harvested subsequently confirmed the clonal nature of these abnormalities (data not shown)

\section{Discussion}

Increasingly, new methods have been adapted and applied to the pathological assessment of FNAB, in a variety of malignancies, including flow cytometric assessment and mutational analysis. ${ }^{19,20}$ Reports of cytogenetic analyses performed on FNAB from solid tumours are virtually non-existent and have achieved variable degrees of success. ${ }^{21,22}$ In uveal melanoma cytopathological examination of FNAB has proved of value in the determination of prognosis, ${ }^{2.3}$ and this approach, combined with assessment of prognostically relevant chromosome alterations, ${ }^{14,15}$ may prove highly appropriate.

Uveal melanomas have previously been determined as suitable for cytogenetic analysis, ${ }^{5-15}$ and this investigation implies that the technique is applicable to both short-term and FNAB cultures of all uveal melanomas independent of tumour location or cell type. In vitro growth was established from all the conventional short-term cultures and, although substantially less, also from all the corresponding FNAB cultures. Karyotypes were obtainable from all standard short-term cultures, whilst $60 \%$ of the FNAB cultures provided adequate numbers of cells for assessment. In reality the success rate for FNAB may be higher $(80 \%)$, as continued examination of the remaining material from the partial analyses (cases 5 and 8) provided sufficient cells for completion.

Previous attempts to utilise cytogenetic assessment of FNAB from tumours have indicated differences between the genetic alterations identified by the two methods. ${ }^{22}$ In this investigation, all major clonal alterations were detectable by both procedures. In several instances (cases 2, 4, 5 and 7), the small number of cells examined prevented the original identification of all clonal aberrations, but these were latterly confirmed by extended analysis. It is also of interest that changes which would normally be considered as non-clonal, such as loss of chromosome 10 in case 4 , were represented at the same low level in both short-term and FNAB techniques. The results of this investigation suggest that analysis of the FNAB cultures provides an accurate reflection of the cytogenetic alterations of the tumour, despite the sampling of small areas, and may imply a greater tendency for homogeneity of genetic alterations amongst uveal melanomas. The general agreement in uniformity of results from cytogenetic studies of these tumours, ${ }^{5-15}$ identifies a clear consistency in their chromosome alterations, which this investigation implies can be extended to the sampling of nominal regions of the melonoma.

The recent evidence suggesting that chromosome alterations are an excellent predictor of prognosis in uveal melanoma, ${ }^{14,15}$ combined with the results of this study, suggesting the suitability of these melanomas for FNAB cytogenetic analysis, indicates that this procedure can, in theory, be reasonably performed on small lesions prior to surgical intervention. Although the procedure in principle seems entirely suited to the assessment of lesions in situ, on a cautionary note it is important to consider that these were test FNAB and performed by direct puncture of the tumour under ideal circumstances. However, success rates in situ could be bolstered by using fluorescent in situ hybridisation (FISH) of probes for the prognostically significant chromosome changes. This report indicates that cytogenetic analysis of FNAB cultures from uveal melanomas is feasible, yielding representative chromosome analysis, and would suggest a real application for the procedure in the assessment of these tumours.

We would like to thank Janet White and Christopher Hinch for assistance.

\section{References}

1. Sandberg AA, Chen Z. Cancer cytogenetics and molecular genetics: clinical implications [review]. Int J Oncol 1995; 7:1241-51.

2. Mertens F, Mandahl N, Mitelman F, Heim S. Cytogenetic analysis in the examination of solid tumours in children. Pediatr Hematol Oncol 1994;11:361-77.

3. Choong PFM, Mandahl N, Mertens F, Willén H, Alvegard T, Kreicbergs A, et al. 19p+ marker chromosome correlates with relapse in malignant fibrous histiocytoma. Genes Chromosom Cancer 1996;16:88-93.

4. Mitelman F. Catalog of chromosome aberrations in cancer, 5th ed. New York: Wiley Liss, 1994.

5. Prescher G, Bornfeld N, Becher R. Non-random chromosomal abnormalities in primary uveal melanoma. J Natl Cancer Inst 1990;82:1765-9.

6. Sisley K, Rennie IG, Cottam DW, Potter CW, Rees RC. Cytogenetic findings in six posterior uveal melanomas: involvement of chromosomes 3,6 and 8. Genes Chromosom Cancer 1990;2:205-9.

7. Sisley K, Cottam DW, Rennie IG, Parsons MA, Potter AM, Potter CW, Rees RC. Non-random abnormalities of chromosomes 3, 6 and 8 associated with posterior uveal melanoma. Genes Chromosom Cancer 1992;5:197-200.

8. Dahlenfors R, Tornquist G, Wettrell K, Mark J. Cytogenetical observations in nine ocular malignant melanomas. Anticancer Res 1993;13:1415-20.

9. Horsman DE, White VA. Cytogenetic analysis of uveal melanoma: consistent occurrence of monosomy 3 and trisomy 8q. Cancer 1993;71:811-9.

10. Wiltshire RN, Elner VM, Dennis T, Vine AK, Trent JM. Cytogenetic analysis of posterior uveal melanoma. Cancer Genet Cytogenet 1993;66:47-53.

11. Singh AR, Boghosian-Sell L, Kishore KW, Wary KK, Shields $C L$, De Potter $P$, et al. Cytogenetic findings in primary uveal melanoma. Cancer Genet Cytogenet 1994;72:109-15.

12. Prescher G, Bornfeld N, Friedrichs W, Seeber S, Becher R. Cytogenetics of twelve cases of uveal melanoma and patterns of nonrandom anomalies and isochromosome formation. Cancer Genet Cytogenet 1995;80:40-6.

13. Sisley K, Brand C, Parsons MA, Maltby E, Rees RC, Rennie IG. Cytogenetics of iris melanomas: disparity with other uveal melanomas. Cancer Genet Cytogenet, in press.

14. Prescher G, Bornfeld, Hirche H, Horstemke B, Jockel KH, Becher R. Prognostic implications of monosomy 3 in uveal melanoma. Lancet 1996;347:1222-5. 
15. Sisley K, Rennie IG, Parsons MA, Jacques R, Hammond DW, Bell SM, et al. Abnormalities of chromosomes 3 and 8 in posterior uveal melanoma correlate with prognosis. Genes Chromosom Cancer 1997; 19:22-8.

16. Prescher G, Bornfeld N, Becher R. Two subclones in a case of uveal melanoma: relevance of monosomy 3 and multiplication of chromosome 8q. Cancer Genet Cytogenet 1994;77:144-6.

17. Gordon KB, Thompson CT, Char DH, O'Brien JM, Kroll S, Ghazvini S, Gray JW. Comparative genomic hybridisation in the detection of DNA copy number abnormalities in uveal melanoma. Cancer Res 1994;54:4764-8.

18. ISCN. An international system for human cytogenetic nomenclature (Mitelman F, editor). Basel: Karger, 1995.

19. Krogerus LA, Railo M, Schoultz M, Nordling S. Flow cytometric DNA measurements in aspiration biopsies and surgical specimens of breast cancers. Analyt Quant Cytol Histol 1995;17:309-13.
20. Sato T, Yuyama Y, Watabe K, Okazaki A, Toda K, Okazaki $M$, Hirata K. Detection of p53 gene mutations in fine needle aspiration biopsied breast cancer specimens: correlations with nuclear p53 accumulations and tumour DNA aneuploidy patterns. Cancer Lett 1997;115:47-55.

21. Akerman M, Alvegard T, Eliasson J, Stanislaw G, Mandahl $\mathrm{N}$, Rydholm A, Willen H. A case of Ewing's sarcoma diagnosed by fine needle aspiration. Acta Orthop Scand 1988;59:589-92.

22. Molenaar WM, van den Berg E, Dolfin AC, Zorgdrager $\mathrm{H}$, Hoekstra HJ. Cytogenetics of fine needle aspiration biopsies of sarcomas. Cancer Genet Cytogenet 1995;84:27-31.

23. Char DH, Kroll SM, Miller T, Castro J, Quivey J. Irradiated uveal melanomas: cytopathologic correlation with prognosis. Am J Ophthalmol 1996;122:509-13. 